\title{
Geochemical characteristics and identification criteria of effective source rock in Mesozoic Yanchang Formation, southern margin of Ordos Basin
}

\section{Ying $\mathrm{Wu}^{*}$ and Jingong Zhang}

\author{
Department of Geology, \\ Northwest University, \\ Shaanxi Xi'an 710069, China \\ Email: wuyingbiy@stumail.nwu.edu.cn \\ Email: zhangjg@nwu.edu.cn \\ *Corresponding author
}

\begin{abstract}
The geochemical characteristics of source rock in Mesozoic Yanchang Formation, southern margin of Ordos Basin have not been introduced in literature. In this study, a number of geochemical experiments were conducted to discuss the geochemical characteristics and to establish the identification criteria. It is shown that source rock in the study area can be divided into five types: A1, A2, A3, A4 and B. Based on the detailed oil source correlation, the source rock types in the study area can be identified as: 1) A1, Chang 7 oil shale, is the excellent source rock with large hydrocarbongeneration potential; 2) A2 and A3, mainly Chang 7 dark mudstone, are the effective source rocks with medium hydrocarbon-generation potential; 3) A4 and $\mathrm{B}$, mainly the thin mudstone or carbonaceous mudstone intervals, are the potential source rock with small hydrocarbon-generation potential. [Received: April 22, 2018; Accepted: May 27, 2018]
\end{abstract}

Keywords: southern margin of Ordos Basin; biomarker; geochemical characteristics; oil source correlation; effective source rock; potential source rock; identification criteria.

Reference to this paper should be made as follows: $\mathrm{Wu}, \mathrm{Y}$. and $\mathrm{Zhang}$, J. (2018) 'Geochemical characteristics and identification criteria of effective source rock in Mesozoic Yanchang Formation, southern margin of Ordos Basin', Int. J. Oil, Gas and Coal Technology, Vol. 19, No. 4, pp.379-395.

Biographical notes: Ying $\mathrm{Wu}$ graduated from Xi'an University of Science and Technology in 2009 with MS degree in Petroleum Geology, and engaged in geological research on Ordos Basin for six years in Yanchang Oilfield Co., Ltd. At present, she is a Doctoral Graduate at Department of Geology at the Northwest University of China. Her major is Mineral Survey.

Jingong Zhang graduated from Northwest University in 1987 with MS degree in Petroleum Geology. He has been engaged in petroleum geology and hydrocarbon accumulation mechanism for 30 years. He is a Professor at Department of Geology at the Northwest University of China. 


\section{Introduction}

The southern margin of Ordos Basin has been the key exploration area in China, and the exploration area is confined in Zhenjing, Binchang, Dian Yi and Fu Xian (Figure 1). According to the results of Third Round Resources Evaluation, the petroleum resources in this region is $10.71 \times 10^{8} \mathrm{t}$, accounting for $12.45 \%$ of the total hydrocarbon resources, indicating the proven rate of $2.36 \%$. The oil and gas are widely distributed within Yanchang Formation, mainly in Chang 2, Chang 4+5, Chang 6, Chang 8 and Chang 9 members. The source rocks in this area are Chang 7 and Chang 9 members. However, the research on the geochemical characteristics of source rock is extremely poor, and the identification criteria for source rock has not been established, resulting in the poor understanding about the distribution of effective source rocks (Duan et al., 2006; Guo et al., 2006; Wang et al., 2007; Ding et al., 2011; Zhang et al., 2012; Zhao et al., 2012; Han et al., 2007). In order to solve the above problems, the author studied the hydrocarbon-generation condition and source quality in Mesozoic Yanchang Formation based on the source rock samples and oil samples in the study area, meanwhile, established the identification criteria using aromatic biomarker parameters, conventional geochemical parameters and logging electrical parameters.

Figure 1 Geographic location and well distribution

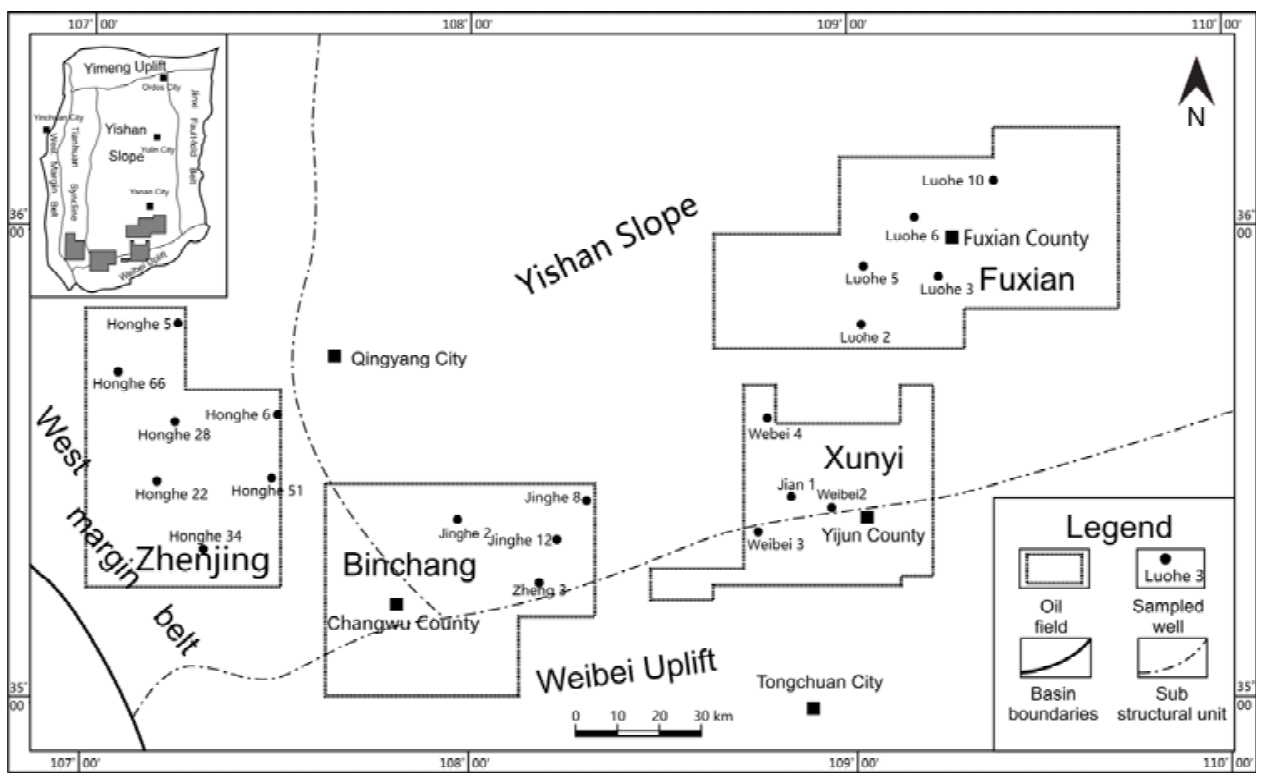

Ordos Basin is a superimposed cratonic basin in China. This basin is bounded by Luliang Mountain on the east, and the Fenwei Mountain on the south, the sub-units includes Shanbei Slope, Yimeng Uplift, Weibei Uplift, Tianhuan Depression, Jinxi Fold Belt and Western Fold-Thrust Belt. The Jurassic is a asymmetric NS-trending rectangular basin with abundant fault-folds in the basin margins. The Yanchang Formation of Jurassic, Ordos Basin is classified into five combinations from bottom to top, i.e., the first one is Chang 10 member (or oil group); the second one includes Chang 9 and Chang 8 members (or oil groups); the third one is Chang 7, Chang 6, and Chang $4+5$ members (or oil 
groups); the fourth one is Chang 3, and Chang 2 members (or oil groups); the fifth one is Chang 1 member (or oil group) (He, 2003; Wu et al., 2004). The Jurassic paleo-lake began to form during the sedimentary period of Chang 10, the paleo-lake underwent rapid subsidence during the sedimentary period of Chang 9 , the paleo-lake was enlarged during the sedimentary period of Chang 8 , the paleo-lake reached its largest burial depth during the sedimentary period of Chang 7 , the paleo-lake began to shrink during the sedimentary period of Chang 6, the paleo-lake shrinked and disappeared during the sedimentary period of Chang 4+5-Chang 1. Owing to the unbalance tension during the sedimentary period of Chang 7, the area of paleo-lake reached its largest area, and the lake evolved into a deep lake. In the southern part of Ordos Basin, the thickness of Chang 7 can reach up to $30-50 \mathrm{~m}$, indicating a large area of deep lake, and the source provenance came from five directions around the basin, mainly from northeast and southwest. In the north part and west part of the study area, the Jurassic sediments are relatively thick.

\section{Samples and experiment}

The samples were collected mainly from potential source rocks, including Chang 4+5, Chang 6, Chang 7, Chang 8, and Chang 9 members. The quantity of samples collected from each member is listed in Table 1.

Table 1 Samples collected from source rocks

\begin{tabular}{lcccccc}
\hline Types & Classification & Chang 4+5 & Chang 6 & Chang 7 & Chang 8 & Chang 9 \\
\hline Rock & A1 & & & 11 & & \\
samples & A2 & & 2 & 5 & & \\
& A3 & & 4 & 3 & & \\
& A4 & 4 & 6 & 9 & 2 \\
\hline Oil samples & B & 3 & & 6 & 14 & 7 \\
& I & 3 & 2 & & 1 & \\
& II & & 1 & 1 & & 1 \\
\hline
\end{tabular}

The experiments include pyrolysis analysis, TOC measurement, maceral component analysis, Chloroform asphalt ' $A$ ' extraction, group component separation and the GC-MS analysis. All the experiments were conducted by the State Key Laboratory of Petroleum Resources and Prospecting, China University of Petroleum-Beijing.

The Rock-Eval Pyrolysis was measured using Rock-Eval equipment, the procedure is as follows:

1 dry the powdered sample for 5 minutes using $90^{\circ} \mathrm{C}$ nitrogen

2 detect the light hydrocarbon and measure the S0 value

3 increase the temperature to $300^{\circ} \mathrm{C}$ and keep it for 5 minutes, measure the $\mathrm{S} 1$ value

4 increase the temperature to $600^{\circ} \mathrm{C}$ and keep it for 5 minutes, measure the $\mathrm{S} 2$ value.

Total organic carbon was measured using dry combustion weighing method, the procedure is as follows: 
1 remove inorganic carbon using diluted $\mathrm{HCl}(8 \%)$

2 burn the remaining in oxygen flow

3 adsorb burning gas using asbestos

4 calculate TOC content according to the lost weight.

In the GC-MS analysis, the measuring instrument used in this study is TRACE DSQ GC/MS. The measuring conditions are as follows: carrier gas is helium, the inlet temperature is $300^{\circ} \mathrm{C}$, temperature of transmission tube is $300^{\circ} \mathrm{C}$; the column is $\mathrm{HP}-5 \mathrm{MS}$ elastic capillary column $(60 \mathrm{~m} \times 0.25 \mathrm{~mm} \times 0.25 \mathrm{~m})$. The heating was conducted through the following procedures:

1 keep the initial temperature at $50^{\circ} \mathrm{C}$ for 1 minute

2 increase the temperature to $120^{\circ} \mathrm{C}$, with the heating rate of $20^{\circ} \mathrm{C} / \mathrm{min}$

3 increase the temperature to $250^{\circ} \mathrm{C}$, with the heating rate of $4^{\circ} \mathrm{C} / \mathrm{min}$

4 increase the temperature to $310^{\circ} \mathrm{C}$ and keep it for 30 minutes, with the heating rate of $3^{\circ} \mathrm{C} / \mathrm{min}$.

The flow rate of carrier gas is $1 \mathrm{~mL} / \mathrm{min}$. In the electron bombardment, the heater current is $100 \mu \mathrm{A}$, multiplier voltage is $1,200 \mathrm{eV}$.

Table 2 Geological parameters of source rocks in different areas

\begin{tabular}{lccccc}
\hline Member & Lithology & $\begin{array}{c}w(T O C) \\
(\%)\end{array}$ & $\begin{array}{c}S 1+S 2 \\
\left(\mathrm{mg} \cdot g^{-1}\right)\end{array}$ & $\begin{array}{c}H I \\
\left(\mathrm{mg}^{-1}\right)\end{array}$ & $\begin{array}{c}\text { RO } \\
(\%)\end{array}$ \\
\hline Chang 4+5 & $\begin{array}{c}\text { Dark } \\
\text { mudstone }\end{array}$ & $\frac{0.80 \sim 2.70}{1.34(7)}$ & $\frac{0.73 \sim 4.20}{1.62(7)}$ & $\frac{52 \sim 147}{97(7)}$ & $\frac{0.88 \sim 0.92}{0.89(3)}$ \\
Chang 6 & $\begin{array}{c}\text { Dark } \\
\text { mudstone }\end{array}$ & $\frac{0.71 \sim 4.00}{1.81(6)}$ & $\frac{0.43 \sim 13.50}{4.70(6)}$ & $\frac{39 \sim 308}{170(6)}$ & $\frac{0.68 \sim 0.89}{0.79(3)}$ \\
Chang 7 & $\begin{array}{c}\text { Dark } \\
\text { mudstone }\end{array}$ & $\frac{0.62 \sim 4.90}{2.92(17)}$ & $\frac{0.62 \sim 17.90}{9.23(17)}$ & $\frac{71 \sim 318}{194(17)}$ & $\frac{0.68 \sim 0.76}{0.72(5)}$ \\
Oil shale & $\frac{3.92 \sim 22.50}{12.90(13)}$ & $\frac{27.10 \sim 120.10}{76.12(13)}$ & $\frac{376 \sim 727}{590(13)}$ & $\frac{0.53 \sim 0.76}{0.62(7)}$ \\
Chang 8 & $\begin{array}{c}\text { Darbonaceous } \\
\text { mudstone }\end{array}$ & $\frac{4.10 \sim 6.80}{5.13(3)}$ & $\frac{7.70 \sim 16.50}{11.01(3)}$ & $\frac{179 \sim 236}{204(3)}$ & $\frac{0.95 \sim 0.95}{0.95(1)}$ \\
Dhank & $\frac{0.59 \sim 4.40}{2.10(13)}$ & $\frac{0.42 \sim 37.84}{7.81(13)}$ & $\frac{51 \sim 252}{151(13)}$ & $\frac{0.71 \sim 0.94}{0.85(7)}$ \\
& $\begin{array}{c}\text { Dark } \\
\text { mudstone }\end{array}$ & $\frac{0.93 \sim 2.10}{1.42(7)}$ & $\frac{0.91 \sim 12.50}{4.21(7)}$ & $\frac{67 \sim 225}{157(7)}$ & $\frac{0.76 \sim 0.92}{0.84(5)}$ \\
\hline
\end{tabular}

Note: $\frac{\text { Minimum } \sim \text { Maximum }}{\text { Average (samples) }}$. 


\section{Hydrocarbon-generation potential}

Geological parameters for source rock in different members are listed in Table 2. The quality of Chang 7 member is excellent source rock, this result is in agreement with previous studies (Wang et al., 2013; Wang et al., 2015; Fan et al., 2017). For the dark mudstone, oil shale and carbonaceous mudstone of Chang 7 member, the average contents of organic carbon are $2.92 \%, 12.9 \%$ and $5.13 \%$ respectively; the average contents of hydrocarbon potential are $9.23 \mathrm{mg} / \mathrm{g}, 76.12 \mathrm{mg} / \mathrm{g}$ and $11.01 \mathrm{mg} / \mathrm{g}$ respectively; the average contents of hydrogen index are $194 \mathrm{mg} / \mathrm{g}, 590 \mathrm{mg} / \mathrm{g}$ and $204 \mathrm{mg} / \mathrm{g}$ respectively. For Chang 7 member, oil shale belongs to good source rock, dark mudstone belongs to medium source rock, carbonaceous mudstone belongs to poor source rock. The mature dark mudstone developed in Chang 4+5, Chang 6, Chang 8 and Chang 9 members, have good abundance of organic matter, and Poor organic types. In contrast, the abundance of organic matter of Chang 6, Chang 8 and Chang 9 are higher than that of Chang $4+5$, the types of organic matter of Chang 6 , Chang 8 and Chang 9 are higher than that of Chang $4+5$.

\section{Source rocks and crude oils}

\subsection{Division of source rocks}

The commonly used biomarkers are n-alkanes, isomeric alkanes (isomerism, trans-isomerism, acyclic isoprene alkane), dicyclic sesquiterpenes, diterpenes (tricyclic, tetracyclo), pentacyclic triterpene (hopane series, non-hopane series), polyterpene, steroid as well as all kinds of aromatic, oxygenated compounds, and nitrogen compounds. In the north part of Ordos Basin, the above parameters were widely applied to source rock studies. Some researchers have successfully characterised the effective source rock using C30-rearranged hopane (Zhang et al., 2009; Moldowan et al., 1991; Peters and Moldowan, 1993; Philip and Gilbert, 1986; Farrimond and Teln, 1996). In fact, C30-rearranged hopane, $\mathrm{Pr} / \mathrm{Ph}$ and $8 \beta(\mathrm{H})$-drimane can be integrated together to characterise source rocks, for they are interrelated with the abundance of organic matter, TOC, S1+S2 and HI (Tables 2 and 3). Low $\mathrm{Pr} / \mathrm{Ph}$ and C30-rearranged hopane, high content of $8 \beta(\mathrm{H})$-drimane indicate deep lacustrine sedimentation with anoxia environment, which is favourable for forming excellent source rock; high $\mathrm{Pr} / \mathrm{Ph}$ and C30-rearranged hopane, low content of $8 \beta(\mathrm{H})$-drimane indicate semi-deep and shallow lacustrine sedimentation with sub-oxidation environment. Therefore, according to the distribution of $\mathrm{Pr} / \mathrm{Ph}$, the source rocks of Yanchang Formation in the southern margin of Ordos Basin can be divided into types A and B. The Pr/Ph of source rock A is larger than 2 , and that of source rock B is less than 2. Source rock A can be divided into A1, A2, A3, A4 based on the distribution of C30-rearranged hopane, $8 \beta(\mathrm{H})$-drimane and other biomarkers composition. The biomarker composition and geochemical characteristics of source rock types are shown in Figure 2. 
Table 3 The characteristics of biomarker and geochemical parameters in different source rocks, Yanchang Formation, southern margin of Ordos Basin

\begin{tabular}{|c|c|c|c|c|c|c|}
\hline Type & Biomarkers & Effectiveness & $\begin{array}{l}\text { TOC } \\
(\%)\end{array}$ & $\begin{array}{l}S 1+S 2 \\
(\mathrm{mg} / \mathrm{g})\end{array}$ & $\begin{array}{c}H I \\
(m g / g)\end{array}$ & Lithology \\
\hline A1 & $\begin{array}{l}\mathrm{Pr} / \mathrm{Ph}<2 \text {, low } \mathrm{C} 30 \text {-rearranged } \\
\text { hopane, } \mathrm{C} 30 \mathrm{RH} / \mathrm{C} 30 \mathrm{H}<0.3, \text { high } \\
\text { content of } 8 \beta(\mathrm{H}) \text {-drimane, and } \\
\text { higher than } 8 \alpha(\mathrm{H}) \text {-drimane, } \\
8 \beta(\mathrm{H}) \text {-homodrimane/ } \\
8 \beta(\mathrm{H}) \text {-drimane }<2\end{array}$ & Excellent & 12.9 & 76.1 & 590 & Oil shale \\
\hline $\mathrm{A} 2$ & $\begin{array}{l}\mathrm{Pr} / \mathrm{Ph}<2, \text { medium } \mathrm{C} 30 \text {-rearranged } \\
\text { hopane, } \mathrm{C} 30 \mathrm{RH} / \mathrm{C} 30 \mathrm{H}<0.3, \\
3<\mathrm{C} 30 \mathrm{RH} / \mathrm{C} 30 \mathrm{H}<0.5, \text { high } \\
\text { content of } 8 \beta(\mathrm{H}) \text {-drimane, lower } \\
\text { than } 8 \alpha(\mathrm{H}) \text {-drimane, } \\
8 \beta(\mathrm{H}) \text {-homodrimane/ } \\
8 \beta(\mathrm{H}) \text {-drimane }<2\end{array}$ & Good & 3.8 & 15.7 & 341 & Mudstone \\
\hline $\mathrm{A} 3$ & $\begin{array}{l}\mathrm{Pr} / \mathrm{Ph}<2 \text {, highC } 30 \text {-rearranged } \\
\text { hopane, } \mathrm{C} 30 \mathrm{RH} / \mathrm{C} 30 \mathrm{H}<0.3 \text {, } \\
\mathrm{C} 30 \mathrm{RH} / \mathrm{C} 30 \mathrm{H}>0.5 \text {, high content } \\
\text { of } 8 \alpha(\mathrm{H}) \text {-drimane, lower than } \\
8 \alpha(\mathrm{H}) \text {-drimane, } \\
8 \beta(\mathrm{H}) \text {-homodrimane/ } \\
8 \beta(\mathrm{H}) \text {-drimane }<2\end{array}$ & Good & 3.3 & 10.1 & 255 & Mudstone \\
\hline A4 & $\begin{array}{l}\mathrm{Pr} / \mathrm{Ph}<2 \text {, low } \mathrm{C} 30 \text {-rearranged } \\
\text { hopane, } \mathrm{C} 30 \mathrm{RH} / \mathrm{C} 30 \mathrm{H}<0.3 \text {, low } \\
\text { content of } 8 \beta(\mathrm{H}) \text {-drimane, lower } \\
\text { than } 8 \alpha(\mathrm{H}) \text {-drimane, } \\
8 \beta(\mathrm{H}) \text {-homodrimane/ } \\
8 \beta(\mathrm{H}) \text {-drimane }>2\end{array}$ & Poor & 1.2 & 1.7 & 109 & Mudstone \\
\hline B & $\begin{array}{l}\mathrm{Pr} / \mathrm{Ph}>2, \text { low content of } \\
8 \beta(\mathrm{H}) \text {-drimane (but higher than } \\
8 \alpha(\mathrm{H}) \text {-drimane), } \\
8 \beta(\mathrm{H}) \text {-homodrimane/ } \\
8 \beta(\mathrm{H}) \text {-drimane }>2\end{array}$ & Poor & 3.4 & 8.9 & 168 & $\begin{array}{l}\text { Carbonaceous } \\
\text { mudstone }\end{array}$ \\
\hline
\end{tabular}

Figure 2 The division of source rock types, Yanchang Formation, southern margin of Ordos Basin
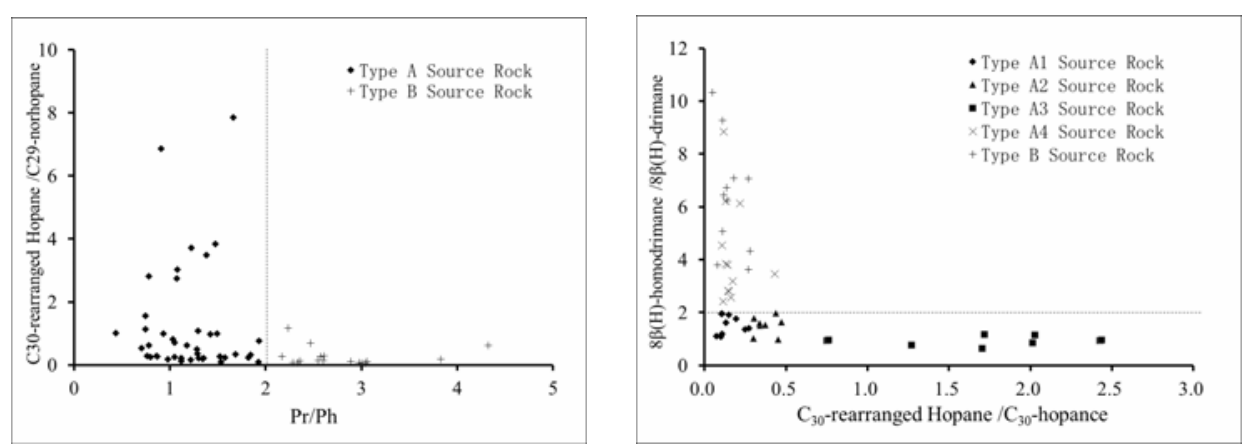
Source rocks with different origins always sediment in different locations, this is also confirmed by this research (Stahl, 1978; Mukhopadhyay et al., 1995). A1 and A2 source rocks mainly distribute within Chang 7 member in Zhenjing, Binchang and Xunyi areas. A3 source rock mainly distributes within Chang 7 and Chang 8 members in Xunyi and Fuxian areas. A1 source rock mainly developed within thick oil shale intervals, whereas A2 and A3 source rocks mainly developed within thick dark mudstone intervals. A4 and B source rocks distribute within the whole Yanchang Formation among the study area, and their lithologies include dark mudstone and carbonaceous mudstone.

\subsection{Division of oil types}

For Yanchang Formation, the maturity of each member have little difference due to that they are controlled by the same sedimentary environment, resulting in that oil related biomarkers have no difference(Wang and Fan, 2016; Peng et al., 2017). For the oil related biomarker compositions as well as source related biomarker compositions, the difference exists within two parameters, i.e., $8 \beta(\mathrm{H})$-drimane and C30-rearranged drimane. Thus, crude oil in the study area can be divided into three types based on the contents of $8 \beta(\mathrm{H})$-drimane and $\mathrm{C} 30$-rearranged drimane (Figures 3 and 4 ).

For type I oil, the content of $8 \beta(\mathrm{H})$-drimane is relatively high (the content is higher than that of $8 \alpha(\mathrm{H})$-drimane), the value of $8 \beta(\mathrm{H})$-homodrimane $/ 8 \beta(\mathrm{H})$-drimane is between $0.69 \sim 1.97$, with an average value of 1.24; the content of C30-rearranged drimane is very low, the value of $\mathrm{C} 30$-rearranged drimane/C30-hopance ranges from 0.02 to 0.35 , the value of C30-rearranged drimane/C29-norhopane is between 0.02 0.97, the value of C30-rearranged drimane/C29Ts is between 0.16 0.97, the value of Ts is close to or slightly higher than that of Tm.

For type II oil, the content of $8 \beta(\mathrm{H})$-drimane is relatively high (the content is smaller than that of $8 \alpha(\mathrm{H})$-drimane), the value of $8 \beta(\mathrm{H})$-homodrimane $/ 8 \beta(\mathrm{H})$-drimane is between 1.01 1.36, with an average value of 1.15; the content of C30-rearranged drimane is secondary large, the value of $\mathrm{C} 30$-rearranged drimane/C30-hopance ranges from 0.35 0.47, the value of C30-rearranged drimane/C29-norhopane is between 1.35 4.06, the value of C30-rearranged drimane/C29Ts is between $0.97 \sim 1.17$, the value of Ts is far higher than that of Tm.

For type III oil, the content of $8 \beta(\mathrm{H})$-drimane is relatively low (the content is smaller than that of $8 \alpha(\mathrm{H})$-drimane), the value of $8 \beta(\mathrm{H})$-homodrimane $/ 8 \beta(\mathrm{H})$-drimane is between $0.89 \sim 1.31$, with an average value of 1.02; the content of C30-rearranged drimane is extremely high, the value of $\mathrm{C} 30$-rearranged drimane/C30-hopance ranges from $0.63 \sim 3.54$, the value of C30-rearranged drimane/C29-norhopane is between 1.55 2.86, the value of C30-rearranged drimane/C29Ts is between 1.88 3.02, the value of Ts is higher than that of Tm.

Biomarker parameters of different oil types are shown in Figure 5. For the three oil types, their $\mathrm{Pr} / \mathrm{Ph}$ values have little difference, with an average value of 1 , indicating that the sedimentary environment for forming source rocks belongs to reducing environment. It also shows, type I oil has the largest values on C30-rearranged drimane/C29Ts, C30-rearranged drimane/C30hopane, C30-rearranged drimane/C29norhopane, whereas, type III oil has the smallest values; type III oil has the largest values on $8 \beta(\mathrm{H})$-homodrimane $/ 8 \beta(\mathrm{H})$-drimane, whereas, type I oil has the smallest values. 
Figure 3 C30-rearranged drimane and $8 \beta(\mathrm{H})$-drimane characteristics of different oils (see online version for colours
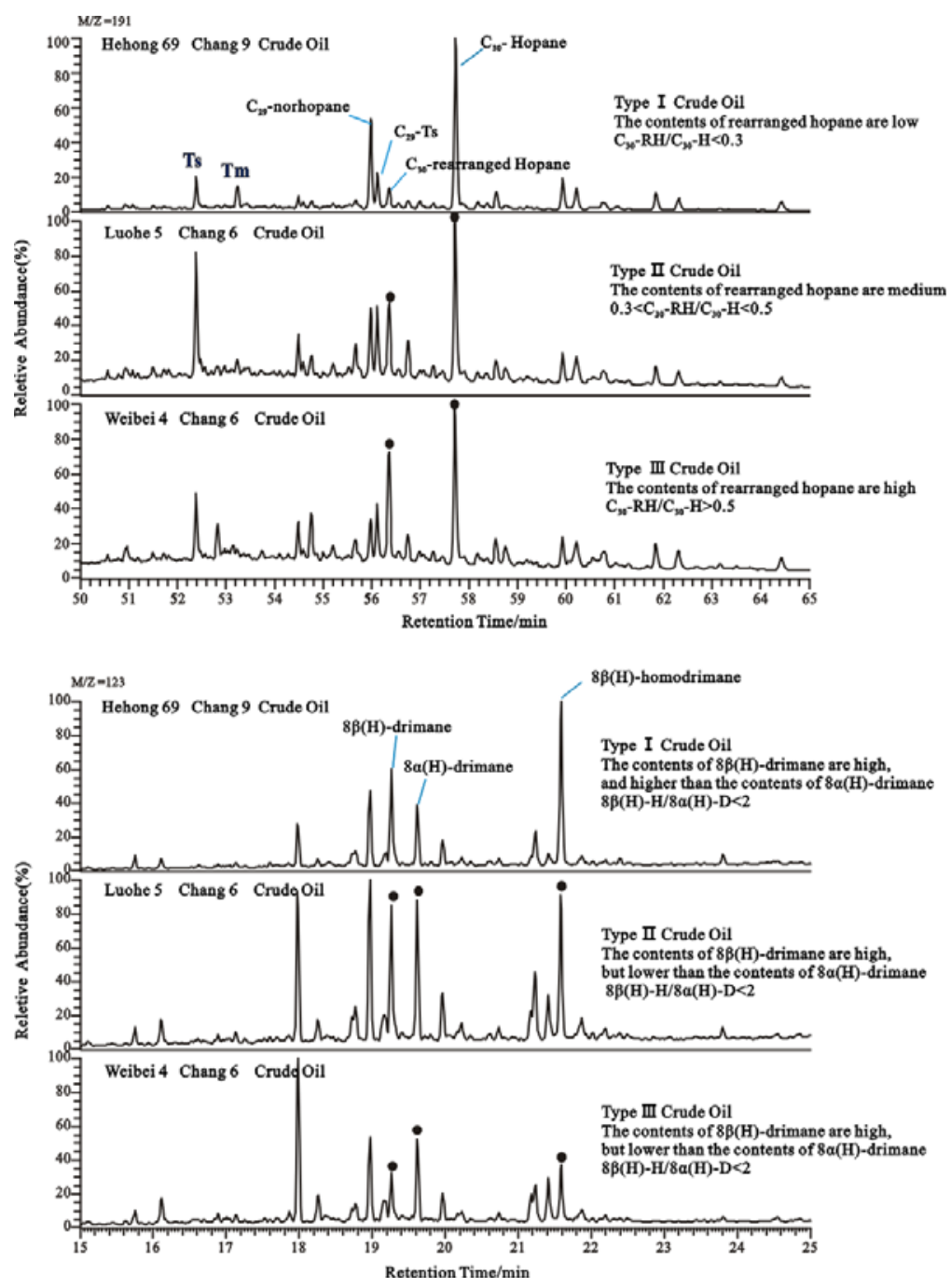

Figure 4 The division of oil types, Yanchang Formation, southern margin of Ordos Basin
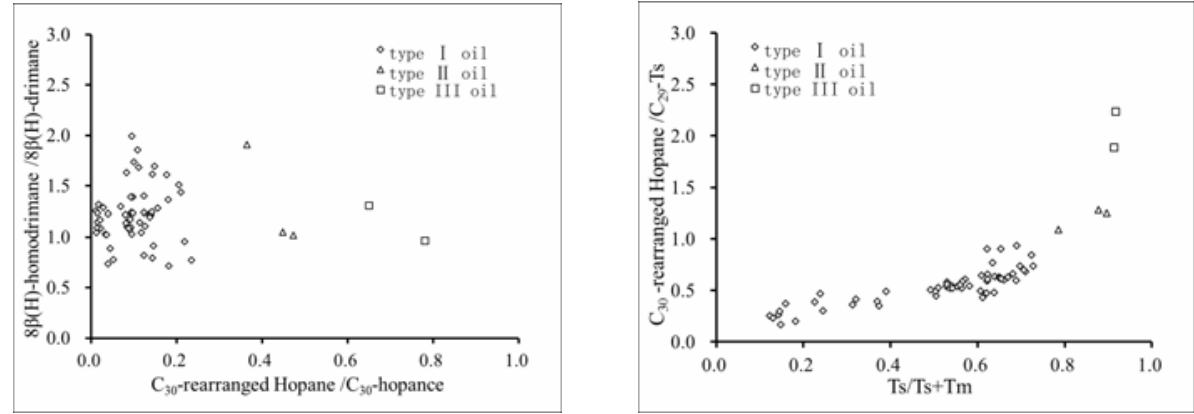
Figure 5 The biomarkers of different oils, Yanchang Formation, southern margin of Ordos Basin (see online version for colours)
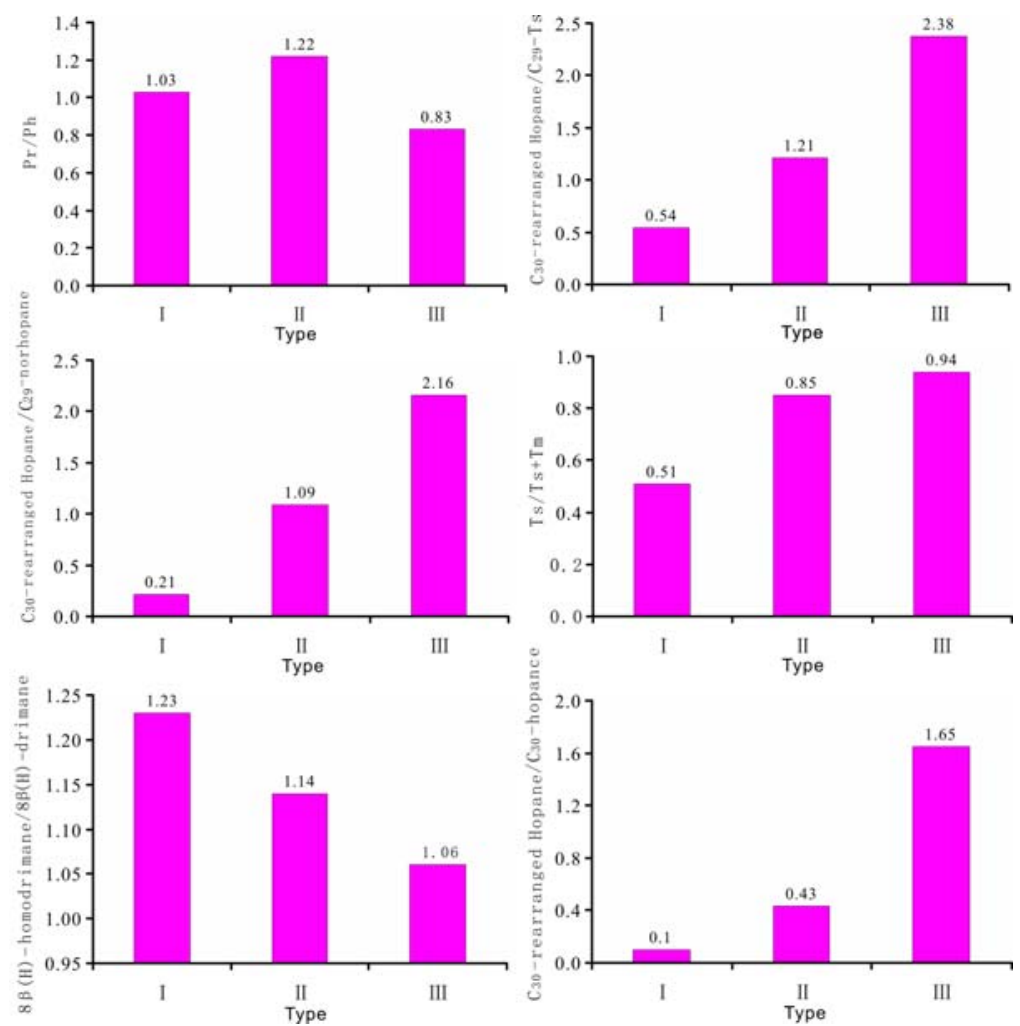

Figure 6 The relative proportions of different crude oils in the different areas (see online version for colours)

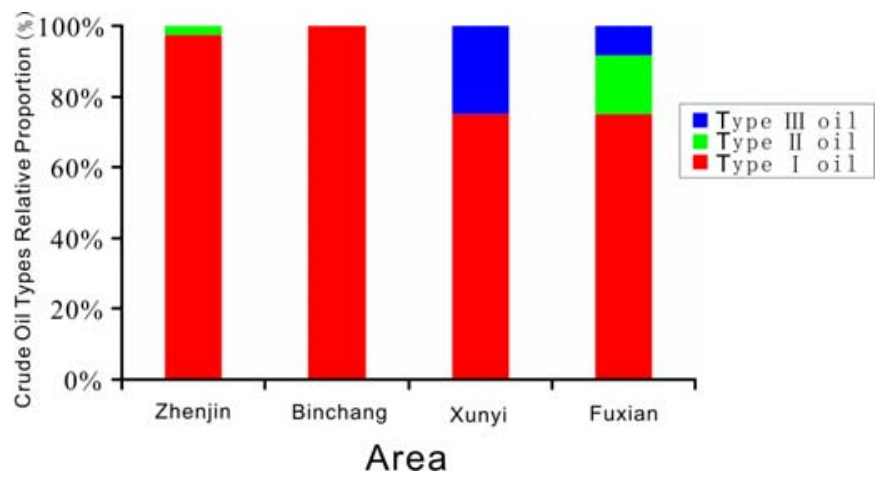

Different oil types distribute in different members and areas in the study area. In Zhenjing area, type I oil is widely distributed in Yanan Formation and Yanchang Formation. In Bingchang area, type I oil is widely distributed in Chang 6 to Chang 8 
members. In Dianyi area and Fuxian area, type I oil is widely distributed in Chang 7 Member and the overlying members. For type II oil, it is widely distributed in Chang 8 Member in Zhenjing area and Chang 6 Member in Fuxian area. For type III oil, it is widely distributed in Chang 6 and Chang 7 members in Dianyi area, and Chang 9 Member is widely distributed in Fuxian area. Thus, type I oil accounts for a large proportion of the crude oil within Yanchang Formation, southern margin of Ordos Basin, and the proportion of type II and type III oil are very small (Figure 6).

\section{Detailed oil-source correlation}

Figure 7 presents the relations between C30-rearranged hopane/C29-norhopane and $\mathrm{Pr} / \mathrm{Ph}$, as well as $8 \beta(\mathrm{H})$-homodrimane/ $8 \beta(\mathrm{H})$-drimane and $8 \beta(\mathrm{H})$-drimane/ $8 \alpha(\mathrm{H})$-drimane. It shows that the Mesozoic crude oil has no relation with type A4 and type B source rocks. Figure 8 presents that the majority of type I, II, III oils have good relation with type A1, A2 and A3 source rocks, showing these oils originated and migrated from A1, A2 and A3 source rocks. In the study area, the dark mudstone of Chang 8 member and a part of Chang 7 member belong to type A3 source rock, the correlation of biomarker distribution (Figure 9) shows that type III oil and dark mudstone of Chang 7 member have high abundance of C30-rearranged hopane, however, their values are lower than that of $\mathrm{C} 30$-hopane. The relative abundance of $\mathrm{C} 30$-rearranged hopane of dark mudstone of Chang 8 member is obvious higher than that of C30-hopane. The $\mathrm{Pr} / \mathrm{Ph}$ and sterane characteristics of type III oil are similar to those of Chang 7 dark mudstone, but differ from those of Chang 8 black mudstone. Therefore, it can be inferred that type III oil mainly comes from Chang 7 dark mudstone. The above analysis shows that Chang 7 oil shale and Chang 7 dark mudstone are the effective source rocks in the southern margin of Ordos Basin, and Chang 7 oil shale is the main effective source rock for providing hydrocarbon.

Figure 7 Comparison of biomarkers between mesozoic oil and source rocks, southern margin of Ordos Basin
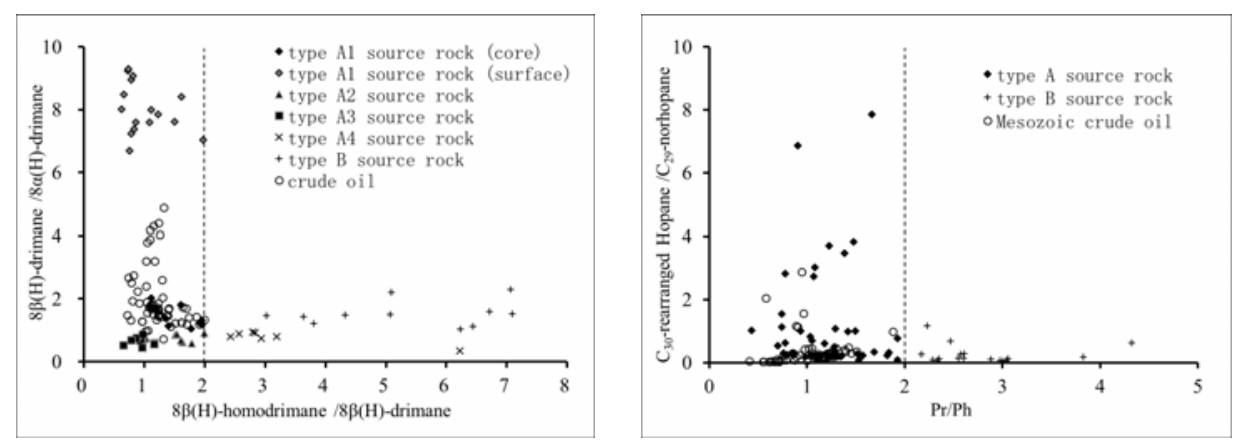
Figure 8 Comparison of biomarkers between different oils and source rocks, southern margin of Ordos Basin
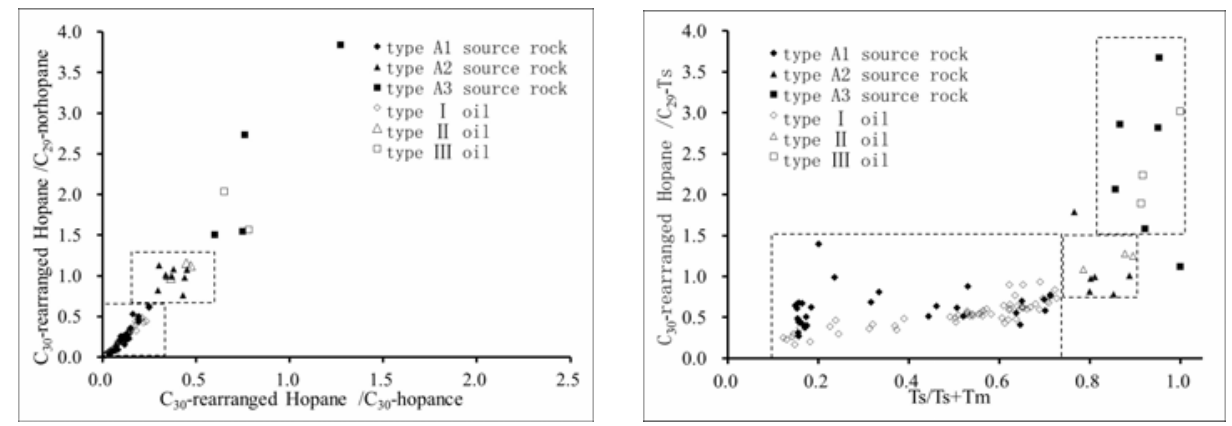

Figure 9 Biomarkers comparison between type III oil and Chang 8 dark mudstone as well as Chang 7 dark mudstone (see online version for colours)
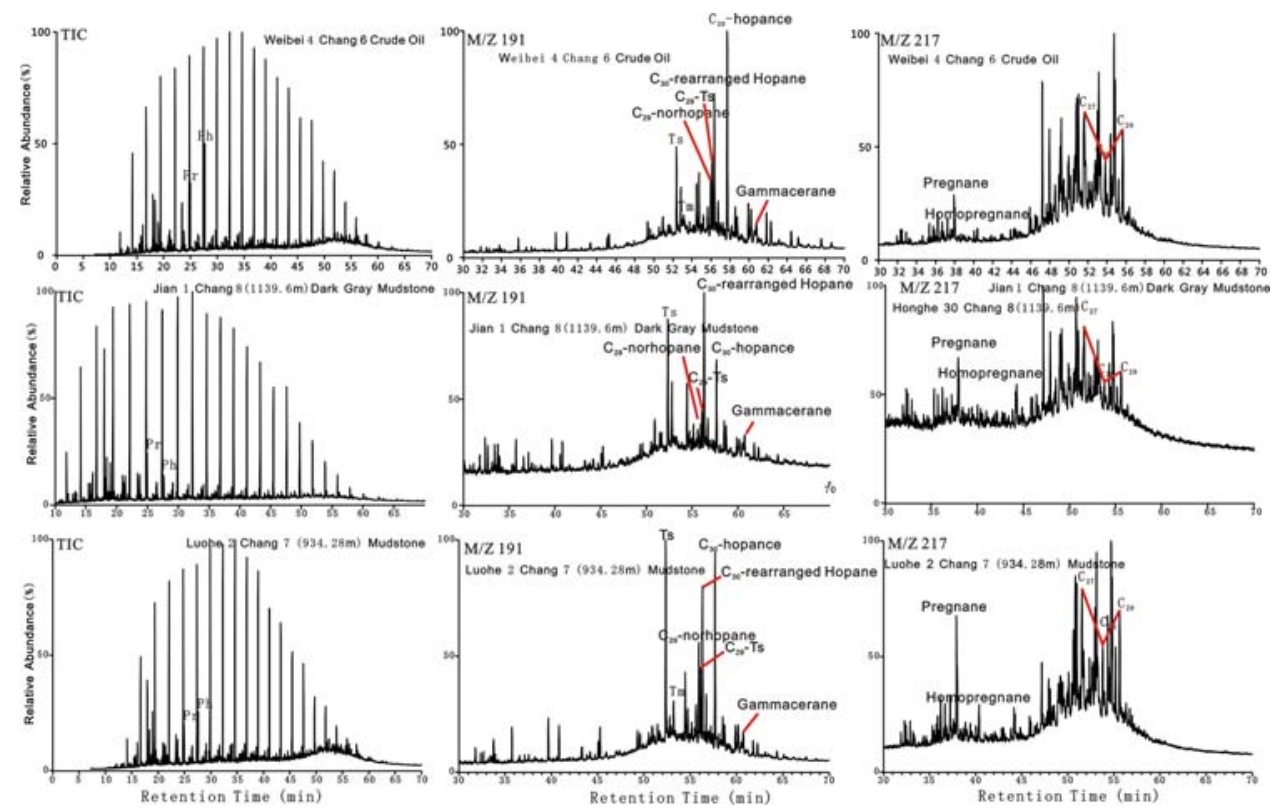

\section{The geochemical characteristics and identification criteria of effective source rocks}

\subsection{The geochemical characteristics of effective source rocks}

The hydrocarbon generating ability of different source rocks varies greatly as shown in Table 4. The TOC of Type A1 effective source rock is $3.9 \%-22.5 \%$, with an average value of $12.9 \%$, the $\mathrm{S} 1+\mathrm{S} 2$ of Type A1 effective source rock is $27.1-120.1 \mathrm{mg} / \mathrm{g}$, with an 
average value of $76.1 \mathrm{mg} / \mathrm{g}$, indicating that type A1 is good source rock; The TOC of type A2 effective source rock is $1.8 \%-5.9 \%$, with an average value of $3.7 \%$, the $\mathrm{S} 1+\mathrm{S} 2$ of type A2 effective source rock is $6.0-32.9 \mathrm{mg} / \mathrm{g}$, with an average value of $16.5 \mathrm{mg} / \mathrm{g}$, indicating that type A2 is the good source rock; The TOC of type A3 effective source rock is $2.1 \%-4.9 \%$, with an average value of $3.6 \%$, the $\mathrm{S} 1+\mathrm{S} 2$ content in type $\mathrm{A} 3$ effective source rocks is $8.1-16.2 \mathrm{mg} / \mathrm{g}$, with an average value of $11.6 \mathrm{mg} / \mathrm{g}$, indicating that type A3 is good source rock. Type A4 and type B also have the capacity of generating hydrocarbon, which are the potential source rock in the study area.

Table 4 Distribution characteristics of organic matter abundance in different source rocks

\begin{tabular}{lcccccc}
\hline Types & $\begin{array}{c}w(\text { TOC }) \\
(\%)\end{array}$ & $\begin{array}{c}S 1+S 2 \\
\left(m g \cdot g^{-1}\right)\end{array}$ & $\begin{array}{c}H I \\
\left(m g \cdot g^{-1}\right)\end{array}$ & $\begin{array}{c}w \text { (Chloroform } \\
\text { asphalt 'A') } \\
(\%)\end{array}$ & $\begin{array}{c}\text { Ro } \\
\%\end{array}$ \\
\hline Excellent & A1 & $\frac{3.9 \sim 22.5}{12.9(9)}$ & $\frac{27.1 \sim 120.1}{76.1(9)}$ & $\frac{376 \sim 727}{590(9)}$ & $\frac{0.19 \sim 1.38}{0.88(7)}$ & $\frac{0.53 \sim 0.76}{0.62(7)}$ \\
Effective & A2 & $\frac{1.8 \sim 5.9}{3.7(5)}$ & $\frac{6.0 \sim 32.9}{16.5(5)}$ & $\frac{267 \sim 531}{380(5)}$ & $\frac{0.11 \sim 0.69}{0.60(5)}$ & $\frac{0.59 \sim 1.02}{0.78(5)}$ \\
& A3 & $\frac{2.1 \sim 4.9}{3.6(8)}$ & $\frac{8.1 \sim 16.2}{11.6(8)}$ & $\frac{172 \sim 481}{261(8)}$ & $\frac{0.29 \sim 0.50}{0.36(4)}$ & $\frac{0.73 \sim 0.94}{0.81(5)}$ \\
Potential & A4 & $\frac{0.6 \sim 2.3}{1.2(16)}$ & $\frac{0.4 \sim 4.5}{1.7(16)}$ & $\frac{39 \sim 218}{1.09(16)}$ & $\frac{0.04 \sim 0.13}{0.04(15)}$ & $\frac{0.71 \sim 0.92}{0.87(7)}$ \\
& B & $\frac{0.6 \sim 8.3}{3.4(16)}$ & $\frac{0.4 \sim 37.8}{10.2(16)}$ & $\frac{51 \sim 473}{187(16)}$ & $\frac{0.05 \sim 0.37}{0.14(17)}$ & $\frac{0.74 \sim 0.95}{0.85(7)}$ \\
\hline
\end{tabular}

Note: $\frac{\text { Minimum } \sim \text { Maximum }}{\text { Average (samples) }}$.

Type A1 effective source rock is composed of type I organic matter; type A2 and type A3 effective source rocks are composed of type II1 organic matter (Figure 10). Type A4 and type B effective source rocks are composed of type II2 and type III organic matters. For type A effective source rock, exinite and asphalt-minerals account for at least $70 \%$ of all macerals components (Figure 11). Meanwhile, Ro is higher than $0.6 \%$, indicating entering into the hydrocarbon generating stage. For type A4 and type B effective source rocks, exinite and asphalt-minerals account for less than $60 \%$ of all maceral components.

The biomarker characteristics of type A effective source rock are as follows (Figure 12): a monomodal n-alkane distribution is observed with a large relative n-alkane concentration in the composition of $\mathrm{nC} 15$ or $\mathrm{nC} 16$; $\mathrm{Pr} / \mathrm{Ph}$ is $0.79-1.29$; the values of gammacerane and $\beta$-carotane are very low, indicating that type A source rock formed in the reducing-weak reducing fresh or mild-saline water environment. The relative content of $\alpha \alpha \alpha 20 \mathrm{RC} 27$ sterane, $\alpha \alpha \alpha 20 \mathrm{RC} 28$ sterane and $\alpha \alpha \alpha 20 \mathrm{RC} 29$ sterane show the shape of ' $\mathrm{L}$ ' or ' $\mathrm{V}$ ' patterns, indicating that aquatic organism like alga has great contribution to source rock; the value of rearrange sterane/sterane is $0.05-0.14$, the content of C30-hopane is extremely high, the content of C30-rearranged hyopane is extremely low, the content of C29-norhopane is medium-high, the content of Ts is lower or close to that of Tm. The biomarker characteristics show that type A effective source rock formed in the reducing environment, with maturity of low-middle maturation. 
Figure 10 Organic matter type in different source rocks

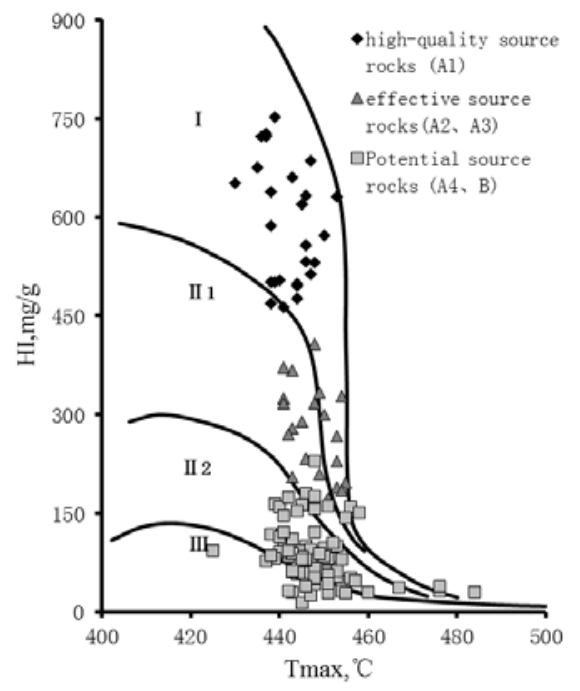

Figure 11 Relative content of maceral components in different source rocks

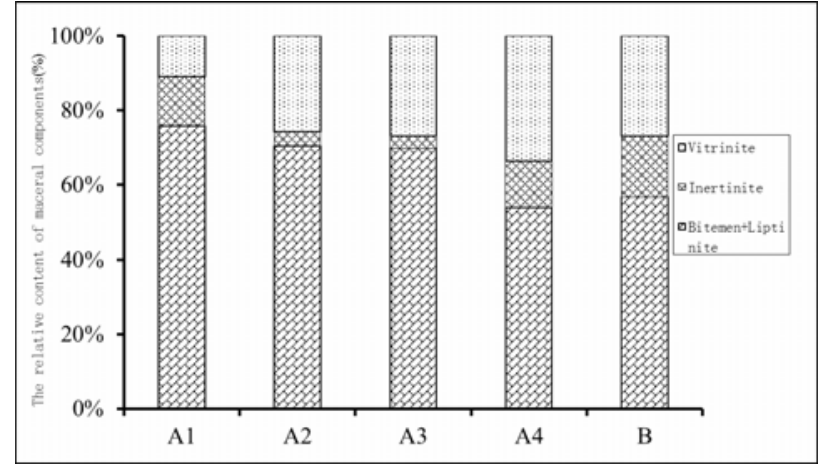

\subsection{The identification of source rocks}

Different source rocks in Mesozoic Yanchang Formation, southern margin of Ordos Basin can be distinguished using biomarker parameters, i.e., C30-rearranged drimane and $8 \beta(\mathrm{H})$-drimane, for they are representatives of different sedimentary environments.

Different source rocks have different hydrocarbon-generation potential. The conventional geochemical parameters such as w(TOC), S1+S2, HI, (S1+S2)/w(TOC) and maceral components can be used to distinguish the different source rocks. The source rocks usually have relatively high gamma ray values and low formation density values than the non-source rocks on well-logging. For the acoustic travel-time differences of kerogen or oil-gas is larger than that of rock skeleton, the acoustic travel-time differences of the formation containing organic matters or oil-gas should be very large. The above properties are the theoretical foundation for identifying the electrical parameters of source rocks (Wang et al., 2002; Zhu et al., 2003; Yan et al., 2009; Zhu et al., 2003). 
Figure 12 Saturates mass chromatogram of effective source rocks, southern margin of Ordos Basin (see online version for colours)

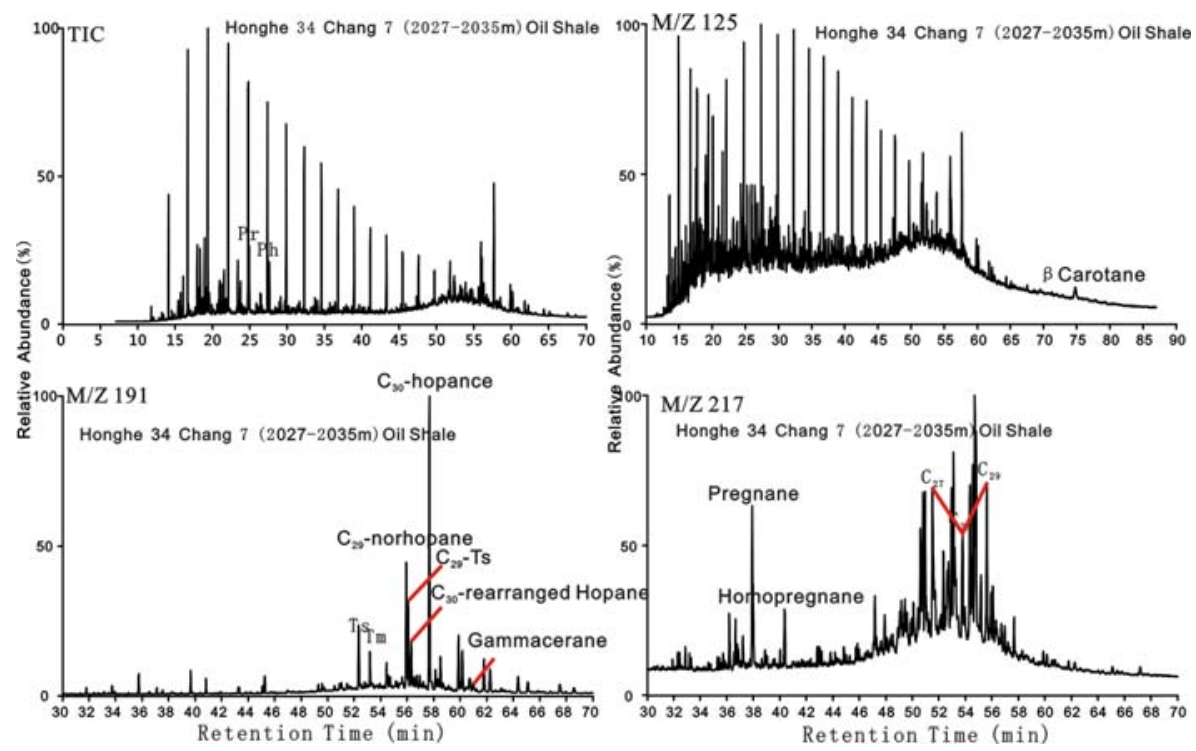

According to the parameters mentioned above, the comprehensive identification criteria for identifying different source rocks can be established. The detailed parameters for identifying different source rocks in the research area are as follows (Table 5, Figure 13), $\mathrm{w}(\mathrm{TOC})>1.6 \%, \mathrm{~S} 1+\mathrm{S} 2>4 \mathrm{mg} / \mathrm{g},(\mathrm{S} 1+\mathrm{S} 2) / \mathrm{TOC}>200 \mathrm{mg} / \mathrm{g}, \mathrm{HI}>170 \mathrm{mg} / \mathrm{g}$; the types of organic matter are mainly type I and type II $1, \mathrm{Ro}>0.6 \%$; carbon distribution of n-Alkane has a single peak with nC15 or nC16 dominating, $\mathrm{Pr} / \mathrm{Ph}<1.8, \alpha \alpha \alpha 20 \mathrm{RC} 27$ sterane $\geq$ C29sterane, $8 \beta(\mathrm{H})$-homodrimane $/ 8 \beta(\mathrm{H})$-drimane $<2$; $\mathrm{AC}>260 \mathrm{us} / \mathrm{ft}, \mathrm{RT}>18 \Omega \cdot \mathrm{m}, \mathrm{CNL}$ $>25 \%$.

Table 5 Identification of source rocks for Yanchang Formation, southern margin of Ordos Basin

\begin{tabular}{lcccc}
\hline Types & Identification parameters & $\begin{array}{c}\text { Excellent } \\
\text { source rocks }\end{array}$ & $\begin{array}{c}\text { Effective } \\
\text { source rocks }\end{array}$ & $\begin{array}{c}\text { Potential } \\
\text { source rocks }\end{array}$ \\
\hline Biomarker & $\begin{array}{c}8 \beta(\mathrm{H}) \text {-homodrimane/ } \\
8 \beta(\mathrm{H}) \text {-drimane }\end{array}$ & $<2$ & $<2$ & $>2$ \\
& $8 \beta(\mathrm{H})$-drimane/ & $>1$ & $<1$ & \\
$8 \alpha(\mathrm{H})$-drimane & $w(\mathrm{TOC}) / \%$ & $>1.6$ & \\
\hline Conventional & $S 1+S 2\left(\mathrm{mg} \cdot \mathrm{g}^{-1}\right)$ & $>20$ & $>4$ & $<4$ \\
geochemistry & $H I\left(\mathrm{mg} \cdot \mathrm{g}^{-1}\right)$ & $>450$ & $>170$ & $<170$ \\
& $S 1+S 2 / w(T O C)\left(\mathrm{mg} \cdot \mathrm{g}^{-1}\right)$ & $>500$ & $>200$ & $<200$ \\
\hline Well-logging & $G R(\mathrm{API})$ & $>170$ & $>120$ & $>100$ \\
& $A C(\mathrm{us} / \mathrm{ft})$ & $>280$ & $>260$ & $<260$ \\
& $R T(\Omega \cdot \mathrm{m})$ & $>15$ & $>15$ & $<25$ \\
\hline
\end{tabular}


Figure 13 Correlation diagram of typical parameters in different source rocks
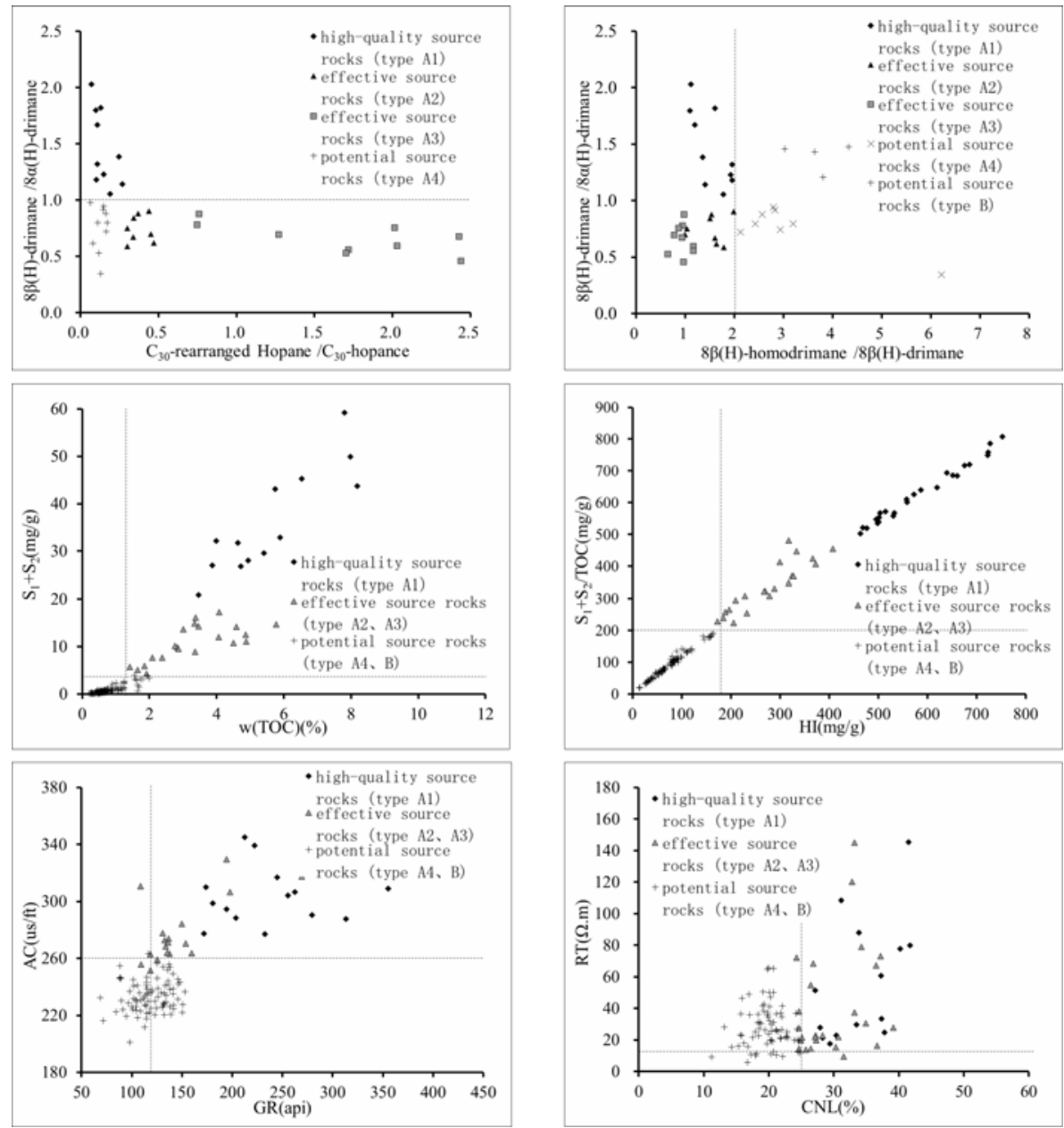

In this study, it is found that the source rocks of Chang 9 member in Zhenjing area are types A4 and B, and that no corresponding oil samples have been found. As the thickness of Chang 9 source rock is excessively thinner than that of Chang 7 source rock, and it distributes partially within the study area, which indicates that Chang 9 source rock only provides a small amount of hydrocarbon, i.e., Chang 9 hydrocarbon in Zhenjing area are mainly provided by Chang 7 oil shale. However, in Fuxian area, Chang 9 source rock probably makes huge contribution to Chang 9 hydrocarbon, for Chang 9 member in this area is the sedimentary centre of source rocks. 


\section{Conclusions}

The drimane, especially the relative content of $8 \beta(\mathrm{H})$-drimane as well as hydrocarbon potential is the key factor representing the types of source rock in southern margin of Ordos Basin. The geochemical parameters including $8 \beta(\mathrm{H})$-drimane, C30-rearranged drimane are reliable to distinguish the source rock types and oil types.

Type I, II, III oils of Mesozoic Yanchang Formation have good correlations with type A1, A2, A3 source rocks, indicating that the three oils originated and migrated from the three source rocks. Chang 7 oil shale and Chang 7 dark mudstone are effective source rocks, and A1 source rock (Chang 7 oil shale) makes large contribution to hydrocarbon accumulation.

\section{References}

Ding, X., Zhang, S., Xie, S., Yi, C. and Xiong, D. (2011) 'Hydrocarbon accumulation system of the Mesozoic in Zhenjing Oilfield,the Ordos Basin', Oil \& Gas Geology, Vol. 32, No. 2, pp.157-164.

Duan, Y., Wu, B., Zhang, H. and Zheng, C. (2006) 'Geochemistry and genesis of crude oils of the Xifeng Oilfield in the Ordos Basin', Acta Geologica Sinica, Vol. 80, No. 2, pp.301-310.

Fan, B., Wang, X. and Wu, X. (2017) 'Desorption analysis of shale and its geochemical characteristics: a case study of the Chang 7 member shale in the central south Ordos Basin', Zhongguo Kuangye Daxue Xuebao/Journal of China University of Mining \& Technology, Vol. 46, No. 3, pp.554-562, in Chinese with English abstract.

Farrimond, P. and Teln, S.N. (1996) 'Three series of rearranged hopanes in Toarcian sediments (northern Italy)', Organic Geochemistry, Vol. 25, Nos. 3-4, pp.165-177.

Guo, Y., Li, W., Chen, Q., Cao, H. and Zhang, D. (2006) 'Geochemical behaviors of oil and oil-source correlation in Yanchang Yan'an formations in Ansai-Fuxian area,Ordos Basin', Oil \& Gas Geology, Vol. 27, No. 2, pp.218-224.

Han, Z., Miao, J. and Bu, Z. (2007) 'The comparative study on organic geochemical characters of the mesozoic source rocks in T3y and J2y of Zhenyuan in Ordos Basin', Geoscience, Vol. 21, No. 3, pp.532-537.

He, Z. (2003) Basin Evolution and Hydrocarbon within Ordos Basin, pp.80-105, Petroleum Industry Press, Beijing.

Moldowan, J.M., Fago, F.J., Carlson, R.M.K., Young, D.C, and Duvne, G.A. (1991) 'Rearranged hopanes in sediments and petroleum', Geochim Cosmochim Acta, Vol. 55, No. 11, pp.3333-3353.

Mukhopadhyay, P.K., Wade, J.A. and Kruge, M.A. (1995) 'Organic facies and maturation of Jurassic/Cretaceous rocks, and possible oil-source rock correlation based on pyrolysis of asphaltenes, Scotia Basin, Canada', Organic Geochemistry, Vol. 22, No. 1, pp.85-104.

Peng, W., Hu, G. and Huang, S. (2017) 'Natural gas geochemical characteristics and genesis a case study of Dongsheng gas field in Ordos Basin of China', Journal of China University of Mining \& Technology, Vol. 46, No. 1, pp.80-90.

Peters, K.E. and Moldowan, J.M. (1993) The Biomarker Guide: Interpreting Molecular Fossils in Petroleum and Ancient Sediments, pp.92-103, Prentice Hall, Englewood Cliffs, NJ (USA).

Philip, R.P. and Gilbert, T.D. (1986) 'Biomarker distributions in Australian oils predominantly derived from terrigenous source material', Organic Geochemistry, Vol. 10, Nos. 1-3, pp.73-84.

Stahl, W.J. (1978) 'Source rock-crude oil correlation by isotopic type-curves', Geochimica et Cosmochimica Acta, Vol. 42, No. 10, pp.1573-1577. 
Wang, G., Zhu, Z. and Zhu, G. (2002) 'Logging identification and evaluation of Cambrian-Ordovician source rocks in syneclise of Tarim Basin', Petroleum Exploration and Development, Vol. 29, No. 4, pp.50-52.

Wang, X. and Fan, B. (2016) 'The desorbing experiments of shale gas and its geological application', Natural Gas Geoscience, Vol. 27, No. 3, pp.532-538.

Wang, X., Fan, B., Zhang, L. and Jiang, C. (2015) 'Reservoir space characteristics and charging process of Lacustrine shale gas - a case study of the Chang 7 member in Yanchang Block in Shanbei slope of Erdos Basin', Oil \& Gas Geology, Vol. 36, No. 4, pp.651-658.

Wang, X., Ren, L., Zhang, L., He, Y., Yang, C. and Duan, X. (2013) 'Oil and source rock correlation of lower assemblage of Yanchang Formation in Wuqi and Dingbian areas,Ordos Basin', Petroleum Geology \& Experiment, Vol. 35, No. 4, pp.426-431.

Wang, Z., Li, Z. and Xi, K. (2007) 'Analysis of main control factor of mesozoic oil and gas accumulation in Ordos Basin of Zhenjing region', Fault-Block Oil \& Gas Field, Vol. 14, No. 3, pp.25-27.

Wu, F., Li, W. and Li, Y. (2004) 'Delta sediments and evolution of the Yanchang formation of upper Triassic in Ordos Basin', Journal of Palaeogeography, Vol. 6, No. 3, pp.307-315.

Yan, J., Cai, J., Zhao, M. and Zheng, D. (2009) 'Advances in the study of source rock evaluation by geophysical logging and its significance in resource assessment', Progress in Geophysics, Vol. 24, No. 1, pp.270-279.

Zhang, W.Z, Yang, H. and Yang, Y.H. (2008) 'Petrology and element geochemistry and development environment of Yanchang Formation Chang-7 high quality source rocks in Ordos Basin', Geochimica, Vol. 37, No. 1, pp.59-64.

Zhang, Y., Chen, C. and Song, Y. (2012) 'Features of mesozoic source rocks and oil-source correlation in southern Ordos Basin', Petroleum Geology \& Experiment, Vol. 34, No. 2, pp.173-177.

Zhao, Y., Luo, A. and Sun, B. (2012) 'Hydrocarbon source evaluation and oil source contrast of the triassic system in southwest margin, Ordos Basin', Journal of Lanzhou University (Natural Sciences), Vol. 48, No. 3, pp.1-5.

Zhu, Z., Liu, H. and Li, Y. (2003) 'The analysis and application of $\Delta \log$ Rethod in the source rock s identification', Progress In Geophysics, Vol. 18, No. 4, pp.647-649. 